\begin{tabular}{llllllll}
$\mathbf{A}$ & $\mathbf{R}$ & $\mathbf{T}$ & $\mathbf{Y}$ & $\mathbf{K}$ & $\mathbf{U}$ & $\mathbf{L}$ & $\mathbf{Y}$ \\
\hline
\end{tabular}

ROCZNIKI FILOZOFICZNE

Tom LXIX, numer $2-2021$

DOI: http://doi.org/10.18290/rf21692-1

\author{
ELŻBIETA ŁUKASIEWICZ
}

\title{
WHY HOPE CANNOT BE AN INTELLECTUAL VIRTUE: RATIONALITY OF HOPE CONSIDERED FROM AN ANALYTIC PERSPECTIVE
}

\section{INTRODUCTION $^{1}$}

In his Essay Concerning Human Understanding, John Locke writes: "hope is that pleasure in the mind, which every one finds in himself upon the thought of a profitable future enjoyment of a thing, which is apt to delight him." Also in Thomas Hobbes" Leviathan, hope is defined in favourable terms as an "appetite with an opinion of obtaining," which is part of more complex virtues such as courage and confidence. ${ }^{2}$ However, that "appetite," or "pleasure in the mind," proves not so obviously desirable on a closer look, and it did receive equivocal evaluation in the Western philosophical tradition. The disposition of hopefulness was often assessed negatively as fundamentally irrational and gullible; grounded in insufficient knowledge and emotional bias, it prevents the human agent from thinking rationally and grasping properly her situation. ${ }^{3}$ Invariably accompanied by fear, hope is the cause of "superstition and false beliefs." It is described as "folly of the

Prof. Dr hab. ElŻBieta ŁuKASIEWICZ - Kazimierz Wielki University in Bydgoszcz, Faculty of Linguistics, Department of English Linguistics; address for correspondence: ul. Grabowa 2, 85-601 Bydgoszcz; e-mail: el.lukas@ukw.edu.pl; el.lukasiewicz@gmail.com; ORCID: https://orcid.org/ 0000-0002-9121-0016.

${ }^{1}$ I wish to express my gratitude to the two anonymous referees for their insightful comments, which helped to improve the original version of the present paper.

${ }^{2}$ In Locke (1975 [1690], II, xx, 9) and HobBes (1998 [1651], I, vi. 14), respectively.

${ }^{3}$ See Plato, Timaeus (1997 [c. 360 BC], 69d); for Plato's more balanced account of hope

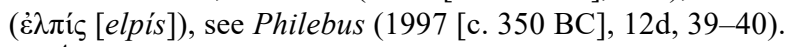

${ }^{4}$ See Seneca, Letters (1969 [c. 60 AD], 5.7-8), Spinoza, Ethics (1994 [1677], III, P50). 
heart" or "the worst of all evils because it prolongs the torments of man"; moreover, hope is considered an obstacle in achieving genuine and proper understanding of the absurdity of human existence. ${ }^{5}$

On the other hand, as argued by Aristotle in The Nicomachean Ethics, hopefulness and confidence are dispositions to be found in the brave man, and they contrast with fear and despair of the coward. John Stuart Mill expresses the opinion of many by writing that "a hopeful disposition gives a spur to the faculties and keeps all the active energies in good working order." Furthermore, the importance of hope transcends individual life; it has a political dimension as people's hopes of obtaining peace or certain goods and profits make them cooperate and obey the rules of social contracts. Hope plays a prominent role in John Dewey's writings on the philosophy of progressive education and meliorism - the view that by constant effort, conditions of life and other things in the world can and should be improved. ${ }^{6}$

One must bear in mind that apart from the "ordinary" sense of the term, hope has a theological reading. For Christians, hope is, next to faith and love, one of three theological virtues, which is indispensable in the pursuit of a good Christian life and attaining, with God's help, eternal happiness and union with God. Thus, it is understandable that in the writings of Augustine, Aquinas and other Christian thinkers, hope in God is attributed a prominent role in human salvation. ${ }^{7}$

As noted by Claudia Bloeser and Titus Stahl (2017), positive, neutral or negative evaluations of hope in philosophical writings largely depend on more general ontological and axiological commitments of particular authors. These commitments concern their worldview and faith in God, as well as an overall optimism or pessimism regarding the human earthly condition and possibility of social or individual progress.

This paper is primarily concerned with hope in its ordinary sense, unrelated to faith. The aim of the paper is twofold: firstly, to critically analyse the claim that hope can be considered an intellectual virtue, as proposed by Nancy E. Snow (2013) in a recent account of hope set within the project of

5 In Schopenhauer (2001 [1851], par. 313), Nietzsche (1910 [1878], par. 71) and Camus (1975 [1942], 112 ff.), respectively. For a detailed historical account of hope in the Western philosophy, see BLOESER and STAHL (2017).

${ }^{6}$ In Aristotle (2009 [c. 300]. III.vii, 1116a), Mill (1969 [1874], 484), Hobbes (1998 [1651], I, xiv, 4), SPINOZA (2002 [1670]: 529) and Dewey (2004 [1916]), respectively.

${ }^{7}$ See St. Paul, Corinthians 13:13; see also Augustine, Enchiridion (1955 [c. 420], II, 7); Aquinas, Summa Theologica (1946 [c. 1265-1273], II, 2, q. xvii-xxii). 
regulative epistemology, and secondly, to explore the issue of rationality of hope. The paper is organized as follows. Section one is concerned with some preliminaries; it explains two different interpretations of the chief notion (hope as a propositional attitude and hope as a disposition), as well as certain characteristic features to be found in these two types of hoping. Section two addresses the key question of the paper, namely, whether hope could be interpreted as an intellectual virtue. The conclusion reached in the section is negative: hope cannot be ascribed the status of a virtue. To develop the main argument against that interpretation, a brief account of the main premises of virtue epistemology is provided, in which special attention is paid to how the notion of intellectual virtue is understood in different branches of virtue epistemology. Section three discusses the problem of rationality of hope along with parallels between a rational belief and a rational hope; this section concentrates on what exactly makes a particular hope-that a rational and justified hope. The criteria of hope's rationality are far less demanding than constraints on what may confer justification on belief; nonetheless, belief that $p$ is possible/probable is part of the meaning of hope that $p$, and therefore, it is assumed that rationality of hope cannot be considered in isolation from rationality of belief. It is argued that the so-called "standard account" of the reasonableness of hope (e.g. DownIE 1963; DAY 1969) does not meet the requirements of epistemic responsibility and needs rectifying; otherwise, hope must be considered a fundamentally irrational attitude. In the final part, section three addresses select arguments concerning hope's rationality and the inadequacies of the standard account offered in recent analytic literature on hope (Bovens 1999; SMith 2008; Martin 2013).

\section{AMBIGUITY OF $H O P E$}

For our discussion of hope's status as an intellectual virtue, it is essential to clarify first what is meant by hope; we shall start with a dictionary explanation of the term. The Oxford English Dictionary $(O E D)$ defines the noun hope as follows:

(a) expectation of something desired; desire combined with expectation (hope of, hope that);

(b) feeling of trust or confidence (hope in); 
(c) a person or thing that gives hope or promise for the future, or in which hopes are centred;

(d) an object of hope, that which is hoped for. ${ }^{8}$

Similarly polysemous is the cognate verb to hope. S hopes that $p$ refers to $S$ 's looking forward and entertaining expectation of something desirable which is specified by the propositional content $p$, while $S$ hopes in $x$ refers to $S$ 's general attitude of trust, confidence or faith in a person or thing $x$, or $S$ 's readiness to rely on $x$. $^{9}$

To exemplify that polysemy: in all the sentences below, there occurs the term hope, but the meaning varies. In (1-2), hope refers to a mental state with a relevant propositional content (i.e. that (1) "the affairs should prosperously succeed and go forward," and (2) "Cornish would appear to have been concerned"). In (3-4), it stands for religious faith or trust in God, whereas in (5), the term may be read as referring to the attitude of trust in someone, without any specific propositional content. Thus, hope may be understood as a propositional attitude (hope-that), as in (1-2), or as a disposition of hopefulness (hope-in), as in (3-5).

(1) The kyng of England beyng in good hope that all his affaires should prosperously succede and go forward, sent to the duke of Burgoyn his vncle the duke of Exceter ...

(2) Great hopes were entertained at Whitehall that Cornish would appear to have been concerned: but these hopes were disappointed ...

(3) 'Tis thou, priest, makest the sky dim: My hope is in the sky.

(4) Leave God to order all thy ways, And hope in him whate'er betide ...

(5) My hopes then are all in you.

Hoping-that is markedly different from hoping-in. Most importantly, someone's hope that $p$ must have a specific propositional content - what is hoped for - which is semantically determinate, i.e. expressed/expressible in a sentence $p$, and can be appraised as desirable, rational, attainable, moral, justified, etc., or not so. Propositional attitudes, regardless whether it is hope, belief, desire, doubt, fear or another, are defined as mental states of

\footnotetext{
${ }^{8}$ OED (2001 [1989]: 376).

${ }^{9}$ OED (2001 [1989]: 377).

${ }^{10}$ The sources for (1-5) are, respectively: Hall, Chronicle, Henry V (1809 [1548], 95); Macaulay, History of England (1849, V. i. 662); MacDonald, The Disciple, (1989 [1867], xxv); Catherine Winkworth's translation of Georg Neumark's Hymn (1855); OED (2001 [1989], 376).
} 
having some attitude to a proposition expressed in a sentence. ${ }^{11}$ In the case of hope, this attitude is a complex state consisting of the subject's desire/wish that $p$ obtains combined with her belief that $p$ is possible/probable. Thus, $S$ hopes that $p$ entails that (i) $S$ wishes that $p$ and (ii) $S$ believes that $p$ is possible/probable. In the philosophical literature on hope, (i) and (ii) have been considered independently necessary and jointly sufficient conditions of the truth of the sentence $S$ hopes that $p .^{12}$ As noted above, these two constituents of hope-that can be appraised morally and prudentially. The moral assessment refers to the desiderative constituent and addresses the question whether it is morally acceptable to wish that $p$, whereas the prudential assessment concerns the estimative constituent, i.e. whether it is rational and justified on $S$ 's part to believe that $p$ is possible/probable. ${ }^{13}$

Hope understood as a disposition (i.e. hopefulness) does not have a specific, semantically determinate content $p$, whose probability, possibility or righteousness might be evaluated. Rather, it is a general mental orientation on the subject's part, characterized by her confidence and trust in someone or something, accompanied by optimism about positive outcomes, future possibilities, etc. In this sense, hopefulness is not very different from optimism. Of course, someone's being in a mental state of hope that $p$ does not entail that the person have a general disposition of hopefulness; these two are distinct things. Nonetheless, this disposition seems to encourage and trigger more occurrences of particular hopes-that.

The divide between particular hopes-that and hope as a disposition pertains to both religious and non-religious contexts of hoping. When Mill writes about the hope that God exists and there is life after death, or when Kant in Critique of Practical Reason argues for the necessity of hope for the immortality of the soul or hope for proportionality between happiness and morality, these are particular hopes-that with specific propositional contents; they are not speaking about the general disposition of hopefulness. ${ }^{14}$

Regarding the temporal aspect of hope, our particular hopes-that may be short- or long-lived mental states, but hope which is a disposition is usually an enduring state. It provides a lasting framework for our cognitive orienta-

${ }^{11}$ See Moser (1999); Schwitzgebel (2015).

12 Downie (1963: 248); Day (1969: 98); but see Bovens (1999); Smith (2008); Meirav (2009); MARTIN (2013); some critical views concerning the standard account will be discussed in section three of the present paper.

${ }^{13}$ See DAY (1969: 93); to the two constituents of hope-that, and in particular to the "possible vs. probable" distinction, we shall return in section four.

${ }^{14}$ See Mill (1969 [1874], 429-489) and Kant (2015 [1788], II, ii, 2-5), respectively. 
tion and capacity to act. Naturally, the fact that someone hopes that $p$, or hopes in $x$, does not imply that the subject be constantly focused on her object of hope. By analogy to the distinction between occurrent and non-occurrent beliefs (MOSER 1999), also hopes may be divided into occurrent or nonoccurrent ones. Only the former require an "online" mental access to their content on the part of the subject; non-occurrent hopes are stored in the subject's memory and are retrieved from it only when they come to the focus of her attention. But, importantly, a non-occurrent hope-that need not be treated as a disposition. ${ }^{15}$ If I hope that I will obtain a grant, it is my particular and semantically well-defined hope-that, not a disposition. And I do not cease to hope that my obtaining a grant is possible and desirable whenever I happen to think about something else; it is then my non-occurrent hope-that.

This double meaning of hope is to be found in Gabriel Marcel's distinction between "I hope that" and absolute "I hope." 16 The former is an expression of hopes for particular outcomes; such hopes depend on external circumstances and are easily disappointed. Far more essential and valued is hope understood in an absolute sense, as a disposition which "tends inevitably to transcend the particular objects to which it at first seems to be attached" $(1951,32)$. That absolute hope allows one to overcome despair, go beyond current limitations, and even "hope against hope" in circumstances which appear hopeless. When commenting on the risk of illusion and disappointment connected with particular hopes-that, Marcel writes:

... in so far as I make my hope conditional I myself put up limits to the process by which I could triumph over all successive disappointments. Still more, I give a part of myself over to anguish; indeed I own implicitly that if my expectations are not fulfilled in some particular point, I shall have no possibility of escaping from the despair into which I must inevitably sink. We can, on the other hand, conceive, at least theoretically, of the inner disposition of one who, setting no condition or limit and abandoning himself in absolute confidence, would thus transcend all possible disappointment and would experience a security of his being, or in his being, which is contrary to the radical insecurity of Having.

This is what determines the ontological position of hope - absolute hope, inseparable from faith, which is likewise absolute, transcending all laying down of conditions, and for this very reason every kind of representation whatever it might be. $(1951,46)$

\footnotetext{
${ }^{15}$ But see Day $(1969,94,98)$.

${ }^{16}$ Marcel (1951 [1942]). Marcel's Sketch of a Phenomenology and a Metaphysics of Hope was originally a lecture given to the Scolasticat de Fourvière during wartime, in February 1942.
} 
In Marcel's writings, that absolute transcending hope (which is different from mere optimism and goes beyond any representations, imaginings and expectations related to hopes-that) is connected with faith in God; his distinction between "I hope that" and absolute "I hope" runs parallel to the distinction between "I believe that" and "I believe" $(1951,32)$. However, hope as a disposition need not be God-oriented; it may be conceived of as a general trust, confidence and openness to the prospect of achieving goals that are meaningful and desirable for human, be it eternal happiness and union with God or some temporal earthly objectives.

Returning to the propositional use of the term, it should be mentioned that a particular hope that $p$ could be conceived of somewhat differently-as a behavioral disposition to act in a certain way. Analogously to the notion of belief (to believe $p$ ), which can be understood as a propositional attitude (i.e. the subject's mental state of accepting proposition $p$ as true) or as a disposition to act as if $p$ is the case ${ }^{17}$ also hope that $p$ might be interpreted dispositionally (behaviorally). Accordingly, to hope that $p$ would mean "to have behavioural dispositions related to $p$ " directed towards achieving the desired aims. But it should be noted that the dispositional interpretation of hope-that is different from the hope-in understood as a disposition of hopefulness, in which the propositional content $p$ need not be specifically formulated (as in Marcel's absolute hope).

The aforesaid "propositional-attitude" interpretation of hope that $p$ does not negate the causal role of hopes in triggering our actions (observable or not); what we hope for may obviously influence how we act. But the focus in the "propositional-attitude" view of hope is elsewhere - not only on the hoper's desire that $p$ and her activity to bring it about, ${ }^{18}$ but also on her evaluation of $p$ as possible or probable (see $\mathrm{i}-\mathrm{ii}$ above). In the dispositionalist approach, the focus will be on the pattern of actual or potential behaviour caused by particular hopes.

On the face of it, it might appear that hopes are well-suited to a dispositional interpretation; they may be considered more amenable to it than beliefs, because someone's hope that $p$ involves a desiderative aspect, possibly conducive to agency, whereas someone's belief that $p$ does not entail that person's wish that $p$. However, as argued below, a dispositional interpretation

${ }^{17}$ It should be noted that W.V.O. Quine and D. Davidson did not regard beliefs as propositional attitudes; for a discussion, see Glock (2003, 268-293). See also Moser (1999) and Schwitzgebel (2015).

${ }^{18}$ Actually, on this view, the subject's desire that $p$ obtains need not involve her agency. 
of hope that $p$ (i.e. as a behavioural disposition directed towards achieving $p$ ) encounters the same problems as the dispositional interpretation of beliefs.

Perhaps the most basic question that dispositionalists must cope with (in the case of beliefs) is whether being disposed to act in a certain way related to $p$ is indeed what is meant by believing $p$. And analogously, one might ask whether our hoping that $p$ is reducible to being disposed to act in a certain way directed towards attaining $p$ - the estimative aspect of hoping-that is clearly lost. Also, if two people react differently to a stimulus, does it imply that they cannot have the same belief, or the same hope? There is also a problem with specifying the conditions under which a given disposition will manifest; this specification seems necessary if we wish to be able to say anything valid about dispositional beliefs or hopes. Moreover, the dispositionalist approach to beliefs and hopes seems explanatorily deficient; it does not explain the role beliefs and hopes play in our acting as we do. When we explain our actions via our beliefs or hopes, we must refer to their content - to what we actually believe or hope for. Otherwise, we are not able to explain the causal power of belief or hope. Finally, the most important advantage of the "propositional-attitude" view of hope-that, to which we shall return in further discussion, is that it allows us to assess the propositional content of someone's hope that $p$ as rational, probable, possible, moral or immoral. This evaluation is essential to be able to consider the problem of virtuousness of hope. Therefore, in what follows, particular hopes-that will not be interpreted dispositionally; the traditional division will be maintained into hope regarded as a propositional attitude (hope that $p$ ) and hope viewed as a general disposition of hopefulness (hope-in).

\section{WHY HOPE CANNOT BE AN INTELLECTUAL VIRTUE}

In this section, I will proceed to the problem indicated in the title of the paper, namely, why hope cannot be interpreted as an intellectual virtue. The disposition of hope/hopefulness has traditionally been regarded as a theological virtue. ${ }^{19}$ However, hope the theological virtue differs a lot from hope viewed as an intellectual virtue. It is sufficient to say that the former is Godoriented and is considered by many to result solely from God's grace, ${ }^{20}$

\footnotetext{
${ }^{19}$ St. Paul, Corinthians 13:13; see also Augustine, Enchiridion (1955 [c. 420], II, 7).

${ }^{20}$ Cf. Aquinas (1946 [c. 1265-1273], Summa Theologica, II-II, q. xxvii-xxii); see also WaWRYKOW $(2012,293-295)$.
} 
whereas intellectual virtues do not necessitate a religious context. They are natural or acquired cognitive faculties or dispositions of character which are knowledge-oriented and allow us to attain truth and avoid error in our everyday epistemic efforts.

A proposal to interpret hope in the framework of virtue epistemology as an intellectual virtue - has been offered by Nancy E. Snow (2013). ${ }^{21}$ Below, I will refer to her interpretation to illustrate the problems involved in that approach. The view defended in this paper is different and might be summed up, in advance, as follows: hope may arise out of intellectual virtues, but it cannot be an intellectual virtue itself. It is not possible because intellectual virtues are dispositions, and if hope is to be assessed as virtuous (i.e. rational and moral), it must be a propositional attitude with a wellspecified propositional content; so it must be a hope-that, not a disposition.

To develop the above argument, it must be explained how the notion of intellectual virtue is defined in different branches of virtue epistemology (henceforth VE). Therefore, we shall start further consideration with a short and, of necessity, very simplified account of this key notion in VE. ${ }^{22}$

VE is a diversified and dynamically evolving movement today, but in all its branches, one general commitment may be observed: compared to other theories of knowledge within analytic epistemology, in VE, there is a shift of attention from the features of justified beliefs to the features of epistemic agents holding those beliefs. Justified belief is defined as one that results from and is a manifestation of intellectual virtues of the person. Thus, intellectual virtues of the believer are defined first, and then belief's justification and knowledge are analysed in terms of their arising out of those intellectual virtues. ${ }^{23}$

The precise scope of the term intellectual virtue may be understood differently in various branches of VE, but it will always involve a kind of reliable, non-accidental cognitive "excellence" in the epistemic agent. ${ }^{24}$ In today's

\footnotetext{
${ }^{21}$ More precisely, SNOw (2013) places her account within the project of "regulative epistemology," where virtue epistemology belongs; see ROBERTs and WoOD (2007). In contrast to theoryoriented analytic epistemology, regulative epistemology is focused on our everyday epistemic practices; it aims to create profiles of particular intellectual virtues and offer epistemic guidance about how responsible epistemic agents should form their beliefs.

${ }^{22}$ Contemporary VE can be dated to the beginning of the 1980's. The approach emerged as a novel and distinct solution to the problem of belief's justification; see Ernest Sosa's seminal paper "The raft and the pyramid: coherence versus foundations in the theory of knowledge" (1980).

${ }^{23}$ See Turri, Alfano, and Greco (2017); Sosa (1991); ZAgZebski (1996 and 1999).

${ }^{24}$ It is worth noting at this point that the concepts of arete in Greek and virtus in medieval Latin both had a broader scope than virtue has in present day English, where the word is largely becoming obsolete - perhaps with the exception of philosophical, religious and ethical dis-
} 
VE, two major views on the nature of intellectual/epistemic virtues can be recognized. Firstly, an intellectual virtue may be regarded as a cognitive faculty, for example, the faculty of perception or memory in humans, by which one is able to attain true beliefs and avoid errors. So is the notion interpreted by "virtue reliabilists": an intellectual virtue is a reliable competence or stable disposition of some kind, innate or acquired, which allows one to achieve a particular epistemic aim - the ultimate goal of which is always attaining the truth. ${ }^{25}$ However, some epistemologists ("virtue responsibilists") distinguish virtues in the proper sense of the word from natural dispositions and skills. They understand the term in an Aristotelian way: as deep, entrenched traits of character possessed by an epistemically responsible person, which are acquired through self-training or by learning virtuous practices from others. A list of intellectual virtues will include: love of knowledge, conscientiousness, perseverance, impartiality, open-mindedness, intellectual courage, caution, intellectual humility, intellectual generosity, practical wisdom and others. ${ }^{26}$ The second approach underlines the connection of virtue epistemology with virtue ethics, as represented by Aristotle's theory of virtues. Similar to acts of moral virtues, which have a twofold structure, involving both a component of motivation to act righteously and a component of non-random success in doing so, acts of intellectual virtues also involve two components: a motivational component, which is a stable and reliable disposition of aiming at truth, and a component of success in reaching the truth. ${ }^{27}$

The two views on the nature of virtues are, obviously, not in conflict; they are rather complementary since both natural dispositions, such as perception or memory, and acquired intellectual virtues, like open-mindedness or conscientiousness, are indispensable in striving for truth. Hence, there are also mixed theories concerning the nature of intellectual virtues, which claim

course. Among Aristotelian virtues we find: excellence of the speculative mind, wit, conversational ability or proper management of money (The Nicomachean Ethics, Books II-IV, VI). Hume's usage of the term (An Enquiry concerning the Principles of Morals) is even broader and refers to practically any moral, intellectual or social trait desirable in a person; for a discussion on the different meanings of virtue, see ZAGZEBSKI (1996, 84-89).

${ }^{25}$ See Sosa $(1991,270-278 ; 2007,22-43)$. In that sense, one could say that intellectual virtues correspond to truth-conducive mental processes in Alvin Goldman's reliabilism (1979), and, with due caveats, they continue the project.

${ }^{26}$ See Montmarquet (1993); Zagzebski (1996). See also Aristotle's The Nicomachean Ethics (ARISTOTLE 2009), where intellectual virtues are discussed in Book VI.

${ }^{27}$ See ZagZeBski (1996, 165-184; 1999, 104-108). 
that they involve both the traits of epistemic responsibility and reliable, truth-conducive natural dispositions. ${ }^{28}$

It is important that intellectual virtues - whatever their nature - should enable us to get to the truth reliably, in a non-accidental way. As in the oftquoted analogy of the archery: a perfect shot hitting the bull's eye may be just a lucky result of some coincidences (shifting winds, etc.), or it may be successful non-accidentally, rather due to the skills of the archer, his talent, inborn capacities and excellent technique mastered during long hours of training; in sum, due to his "virtues" as an archer. Only in the second case does the archer's performance deserve admiration and praise; such a shot is a manifestation of some excellence in that person, not a result of mere luck. The situation is quite similar with true beliefs; they can be valued for success in achieving the goal (i.e. the truth) only if they result from intellectual virtues, whereas beliefs which are true by chance do not deserve creditand do not make knowledge (Sosa 2007, 22-23).

Keeping in mind the two major interpretations of the notion of intellectual virtue in VE, let us return to the aforementioned account of hope as an intellectual virtue by Nancy E. Snow (2013). Her paper is better situated in the second of the above approaches ("virtue responsibilism") since hope is explored as a virtue in the Aristotelian sense, with a moral dimension. Snow adopts the criteria for virtue proposed by Linda T. Zagzebski in Virtues of the Mind (1996); namely, virtues must be appropriately motivated, and exhibit reliable success in the attainment of their ends. For an intellectual virtue, that appropriate motivation consists in the pursuit of truth; intellectual virtues arise from the epistemic agent's desire to have a deep cognitive contact with reality - a contact which entails genuine and thorough understanding, intellectual originality, inventiveness and autonomy. ${ }^{29}$

It follows from the above that if hope is considered an intellectual virtue, it must contribute to one's successful pursuit of truth and intellectual flourishing. Snow proposes three respects in which hope is an intellectual virtue:

(1) hope furnishes a motivation for the pursuit of knowledge/truth; (2) hope imparts qualities to its possessor, such as resilience, perseverance, flexibility, and openness, that aid in the pursuit of knowledge/truth; and (3) hope, through imparting such qualities to its possessor, functions as a kind of method in the pursuit of knowledge/truth. (SNOw 2013, 157)

${ }^{28}$ See Turri, Alfano, and Greco (2017). Sosa's account of intellectual virtues is usually placed in "virtue reliabilism" (see above), but there are passages in his writings (e.g. Sosa 1991, 271) where he seems to adopt a mixed approach.

${ }^{29}$ SNOw $(2013,156)$; see also ZAGZEBSKI $(1996,131-137,197)$. 
In other words, hope is a motivating force in one's search for knowledge/truth; it generates other intellectual virtues aiming, ultimately, at truth; and thus, it creates a method supporting one's further intellectual growth. Let us consider whether this view on hope's prominent place in the epistemic framework is tenable; we shall start with the latter two points.

The claim that hope can impart other epistemic virtues (like resilience, perseverance, flexibility, and openness) to the agent, and thus create a method for epistemic search, seems to be an overrated account of its role. Perhaps hope promotes and strengthens the workings of other virtues, but it is not clear from Snow's account how the other dispositions might be generated by hope alone. Furthermore, from the case-examples provided, it appears that these four dispositions might equally well arise from or be promoted by virtues other than hope, for example, conscientiousness or intellectual curiosity. In his critical appraisal of Snow's account, Aaron D. Cobb (2015) rightly argues that hope as a virtue cannot work alone; virtuous hope needs to be supported, guided and perfected by other epistemic virtues. Thus, due attention should be paid to that interplay between hope and other dispositions:

... intellectual dispositions tend to cluster together; it is their integration in the life of the person that can generate excellent epistemic habits and practices. ... Hope is a constituent of the intellectually virtuous life to the extent that it benefits from the directing, correcting, and perfecting influence of other cognitive excellences. (Совв 2015, 282-283)

However, even if hope cannot be shown to generate, per se, other epistemic qualities and, consequently, it cannot create a method for an enduring epistemic effort (so it fails in points (2-3) of Snow's account), there remains the first claim (1) that "hope furnishes a motivation for the pursuit of knowledge/truth." On the face of it, (1) seems uncontroversial and convincing. Could it secure hope's status as an intellectual virtue?

Undoubtedly, hope motivates one's pursuit of various epistemic ends; knowledge/truth is actively searched for only if one desires it and believes it to be attainable - in sum, if one hopes for knowledge (see the desiderative and estimative constituents of hope discussed in section one). However, the question arises whether this motivating, knowledge-oriented force is enough to regard hope as an intellectual virtue. At this point, we must return to the above-mentioned two criteria for an intellectual virtue: being appropriately motivated and reliably truth-conducive. ${ }^{30}$

\footnotetext{
${ }^{30}$ See ZAGZeBsKi (1996 and 1999).
} 
Snow is clear that "hope's status as an intellectual virtue depends crucially on the motivation for having it, and this motivation must link in appropriate ways with the nature of the end for which one hopes" $(2013,160)$. Thus, hope is not an intellectual virtue if it motivates someone to pursue knowledge for harmful purposes. Nor is it a virtue if someone's hopeful pursuit of knowledge/truth is motivated by sheer career advancement, greed or other selfish gains; motivation generated by and generating hope must be moral and praiseworthy.

No less important is the second criterion: intellectual virtues are stable dispositions which are reliably truth-conducive. They guide the agent in her belief-forming processes and allow her to attain the truth in a reliable and non-accidental way. The obvious question arises whether the disposition of hope is indeed reliably truth-conducive. ${ }^{31}$ This criterion clearly poses a problem since hope, on numerous occasions, fails the reliability test. Snow admits that there are some perils associated with hope, for example, wishful and unrealistic hopes, or hopes incorporating false beliefs, which are doomed to fail, or willful and ill-motivated hopes, in which objectives are blindly pursued without due attention to circumstances $(2013,166)$. Therefore, only rational and well-tuned hope can be regarded as an intellectual virtue. Snow writes:

[O]ne can hope in rationally deficient ways, and when one does, hope is not a virtue. ... I consider hope as a moral and intellectual virtue to occupy a middle ground between the vices of hoping too little and hoping too much. Hoping too little can be associated with fear, with despair, or with simple indifference. As I noted earlier, excessive and willful hoping smacks of presumption. Suffice it to say that when we hope too much we have left the realm in which hope is a virtue. Hoping too much is a vice, just as hoping too little. $(2013,166)$

So, let us repeat, in order to be considered an intellectual virtue, hope must fulfill the above-mentioned criteria of praiseworthy motivation and truth-conduciveness; virtuous hope cannot be immoral or excessive and irra-

${ }^{31}$ However, "reliably truth-conducive" does not entail that a particular disposition be infallibly truth-conducive; reliability of a cognitive process means a sufficiently favourable proportion of true beliefs to false beliefs generated by that process, and, as pointed out by Goldman, the proponent of reliabilism, "perfect reliability isn't required. Belief-forming processes that sometimes produce error still confer justification" (2012 [1979], 38). It should be noted that the vagueness of the reliabilist notion of truth-conduciveness, i.e. lack of precisely formulated standards of reliability, is considered one of the major weaknesses of the approach; see FELDMAN (1985); FolEY (1985). 
tional. Therefore, it is obvious that hope, before it is called "virtuous," must be assessed whether it satisfies these two conditions. But here arises a problem, because such assessment requires that hope be a propositional attitude (hope that $p$ ) with a well-specified propositional content, whose rationality and moral dimension could be evaluated; the disposition of hopefulness does not have such a content (cf. the difference discussed in section one between hoping-that and hopefulness).

Snow does mention the distinction between hope for specific ends (hope that $p$ ) and hope as an ongoing disposition (hopefulness), and it is the latter which is considered an intellectual virtue $(2013,154 \mathrm{ff}$.). This is understandable because intellectual virtues are natural or acquired dispositions of the mind (see above), not propositional attitudes. However, when Snow refers to hoping in rationally or morally deficient ways, it is clear that she is speaking about hopes-that, i.e. hopes as propositional attitudes. Only hopes with propositional contents (hope that $p$ ) can be morally and/or prudentially appraised; in consequence, they can be judged as rational, justified, morally praiseworthy, or the opposite: wishful and unrealistic, or presumptuous. To conclude, the fundamental problem concerning hope's status as an intellectual virtue (i.e. disposition) is that hope cannot be judged as moral/immoral or rational/irrational without referring to what is actually hoped for by the hoper. But when hope is a propositional attitude, it cannot, by definition, be a virtue.

\section{RATIONALITY OF HOPE:}

WHAT MAY CONFER JUSTIFICATION ON HOPE?

As argued above, though hopefulness is a stimulating force for our agency and pursuit of knowledge, we cannot assume that being hopeful, as a general ongoing disposition, is always praiseworthy, rational and desirable. Therefore, we cannot claim that it is an intellectual virtue per se. However, particular hopes-that may be triggered and sustained by epistemic virtues, such as intellectual curiosity, open-mindedness, perseverance, or intellectual courage. If our hope that $p$ is generated by morally impeccable and truth-oriented motivation, and it is rational and justified, this type of hope may be deemed virtuous. The following section will address the question of what exactly makes a particular hope-that a virtuous hope.

Two constituent elements of hope-that were introduced in section one; when interpreted as a propositional attitude, hope is a complex state con- 
sisting of the desiderative aspect (i.e. the subject's desire/wish that $p$ obtains) and the estimative aspect (i.e. her belief that $p$ is possible/probable) ${ }^{32}$ Regarding the desiderative component of hope, it is uncontroversial that someone's virtuous hope that $p$ cannot be immoral, ill-motivated or selfish on the agent's part, and it must involve some good for the agent and/or other people. Much more controversial is the question of what makes a given hope rational and justified. Therefore, in what follows, I will concentrate on the estimative, belief-like, aspect of hope-that and, in particular, on the analogies between hope that $p$ and belief that $p$ (where the latter is understood as "acceptance of proposition $p$ as true"). Constraints on what may confer justification on belief that $p$ are far more demanding than in the case of hope that $p$, however, belief is part of the meaning of hope, and rationality of hope cannot be considered in separation from rationality of belief.

As already mentioned, hope understood as a propositional attitude must be semantically well-defined; i.e. it must be capable of being described in words, typically (but not necessarily) in the form: $S$ hopes that $p$, where $S$ stands for a human subject (the hoper) and $p$ is a proposition in the logical sense, expressed in a sentence referring to what is hoped for by $S$. It is beyond the scope of this paper to discuss the ontological status of propositions which are contents of hopes, beliefs and other propositional attitudes. We will adopt a straightforward view that the content of what is desired and believed by $S$ to be possible/probable, aloud or in thinking, is a proposition, and that proposition is somehow represented in $S$ 's mind (be it Fodor's "language of thought" or otherwise), it is stored there, and it can be retrieved from memory if need be. ${ }^{33}$ But whatever view on the nature of propositions is adopted, it is clear that the propositional content of hope-that must be expressed/expressible in a natural language, be accessible and recognizable to the believer as the content of her hope. Otherwise, one cannot claim that one hopes that $p$.

The above condition is connected with an important question of whether the state of hoping that $p$ (i.e. the subject's desiring that $p$ and her believing that $p$ is possible/probable) implies that the subject should have the concept of belief/hope and be capable of reflecting on the fact that she hopes so-andso. This question concerns the subject's ability to form meta-beliefs on some occasions; it is not the question whether all her hopes, beliefs, desires and

\footnotetext{
${ }^{32}$ So is hope-that described in the so-called "standard" or "orthodox" accounts; select works offering critique of this view are discussed in the final part of the section.

${ }^{33}$ See Fodor (1975); see also SchwitzGebel (2015).
} 
other propositional attitudes are self-conscious states. The fundamental condition for having beliefs about one's hopes, beliefs and desires is language. But since we are discussing hope understood as a propositional attitude, the condition of having language is taken for granted (see above); in order to have a hope-that, one must have language to express the hope's content. ${ }^{34}$ But is it necessary that the subject who is ascribed a hope that $p$, whose constituent is a belief that $p$ is possible/probable, be able to form beliefs about her hope, that is, to have (at least some) meta-beliefs?

In Inquiries into Truth and Interpretation, Donald Davidson thus argues for the necessity of having the concept of belief: "someone cannot have a belief unless he understands the possibility of being mistaken, and this requires grasping the contrast between truth and error - true belief and false belief" (2001 [1984]: 170). Therefore, the fact that some of our beliefs are false and are recognized as such by us entails our having the concept of mistake. But one cannot imagine having a concept of being mistaken without a concept of belief, which is more fundamental than the former. Therefore, it must be assumed that the capacity to believe or hope that $p$ entails the capacity of being aware that one believes or hopes that $p$.

It should be noted at this point that the aforementioned VE does not maintain such internalist premises. In VE, an "apt" belief (i.e. a justified true belief in Sosa's terminology) owes its aptness to the intellectual/epistemic virtues of the believer, but she need not be aware of the workings of her epistemic virtues (innate or acquired), and she need not be able to provide any reasons in favour of the relevant belief. Aptness could be defined as mere truth-conduciveness of a given faculty. ${ }^{35}$ On the other hand, it is clear that many of our beliefs, even the very ordinary, enjoy considerable support from some meta-beliefs; we are often aware how it came about that we hold this or that belief and that it is coherent with the rest of our beliefs. In Sosa's account, the ability to evaluate one's belief as coherent with other beliefs is considered an intellectual virtue in itself; such "second-order intellectual virtues" constitute a higher and more sublime level of knowledge, the socalled "reflective knowledge" (1991, 144-145). I assume that a virtuous

${ }^{34}$ It is beyond the scope of this paper to discuss the nature of hopes held by human infants and primates, and whether they have any. For our purposes, suffice it to say that hope understood as a propositional attitude requires language; therefore, a human infant without developed language or a chimpanzee cannot hope that $p$, which does not negate their possessing certain behavioural dispositions or cognitive schemes, but these are not hopes-that in the sense adopted in the present paper.

${ }^{35}$ Cf. externalist premises in reliabilism; Goldman (2012 [1979], 42). 
hope, similarly to virtuous (not merely apt) beliefs, also requires secondorder awareness that our hoping that $p$ fits coherently within our system of other hopes, beliefs and desires; this type of reflective knowledge is simply necessary to achieve a properly human understanding of one's epistemic situation.

Ascribing moral and rational hopes to someone makes sense only if the person is in a position to identify those hopes, to pick them out from the overall body of her hopes, desires and beliefs, and assess them as rational and justified. Therefore, in the debate between atomism and holism, ${ }^{36}$ the former position appears more convincing. By this claim I do not aim to negate the obvious fact that the content $p$ of someone's hope (or belief) and the degree of confidence therein depend to a large extent on the person's other hopes, desires and beliefs, her previous experiences, worldview, educational background, etc. Thus, a child's attitude of regarding $p$ as possible/ probable will be somewhat different from an adult's thinking of $p$ as possible/probable. Nevertheless, it must be assumed that if two people whose cognitive situation is different, like in the above case, both regard proposition $p$ concerning an object or state of affairs as possible/probable and desirable, and they do so with sincerity and understanding, they can be said to hope the same thing. (Whether they are equally justified in believing that $p$ is possible/probable is a different issue, to which we shall return.) That simplification is necessary; otherwise, we would end up on a holistic slippery-slope where the multitude of supporting beliefs, other hopes and desires, and the intricacies involved in our forming a particular hope would not allow us to grasp it as a distinct hope with a specific discrete content. In effect, none of our hopes would be recognizable as such and we would not be able to say anything sound about what we hope for. Therefore, someone's hope that $p$ cannot be conceived of as a holistic, elusive and inexpressible mental state of that person, of strictly "private" nature, because neither the person nor we could say anything valid about such hope, and it would not make an interesting concept.

A justified and rational hope does not have to prove true, and significantly, a hope which comes true does not have to be rational and justified. To take an example, if Mr Jones seeks advice of a clairvoyant to invest his money and learns from that person that the company $A$ is a promising enterprise on the stock market, his hope regarding possible profits will not

\footnotetext{
${ }^{36}$ Cf. SchwitzGebel (2015: section 3.2); see also Davidson (2001 [1984]).
} 
be properly justified, even if $A$ is indeed a sound investment. We could not say that Mr Jones rationally hopes that the company $A$ is worth investing in. To meet requirements for being epistemically justified, the belief constituent of hope must be based on good evidence, the source of which is usually sound reasoning, past experience, or testimony of a reliable person. It is clear that hopes based on superstitions or wishful thinking cannot be virtuous hopes, even if they happen to be true.

The estimative aspect of hope-that, i.e. believing that something is possible or probable, is not an all-or-nothing affair; it comes in degrees. If we use a scale from 0 to 1 to represent the degree of conviction that $p$ will obtain/obtains, point 0.5 means that the subject considers $p$ as likely to be true as false, and the extreme points, 0 and 1 , indicate lack of any confidence and absolute certainty, respectively. In both latter cases hope is impossible: $S$ hopes that $p$ entails that (1) A does not know whether $p$, and (2) A wishes that $p$, and (3) $A$ thinks that $p$ is in some degree possible/probable. It is uncontroversial that one cannot hope for the certain or for the impossible; however, (3) allows for markedly different interpretations. So far in the paper, the compound expression possible/probable was used to cover the unspecified degree of probability that $p$, but the key issue in the appraisal of hope's rationality is whether the hoper thinks the object of hope to be highly probable, more probable than not, probable in some minimal degree, or merely possible (but perhaps improbable).

J.M.O. Wheatley (1958) claims that hoping involves some degree of expectation; thus, I hope that $p$ entails that I believe that $p$ is possible (not only logically, but also physically) and I have some degree of belief that $p$ obtains/will obtain. Wheatley writes:

Considering (3) ("I hope that Smith went"), I want to say first that while it entails that I do not fully believe that Smith went it also entails that I do half-believe that he went, that I should be more or less disappointed or surprised to learn that he did not go. The strength of my half-belief may be roughly indicated by the tone of voice and context in which I utter it. ... To hope, regarding the future, is in part to expect but not to be sure. And if a person is hopeless what he lacks is not a desire but an expectation that his desire will be met. The fact that hoping involves some degree of expectation underlies the use of such expressions, surely, as "false hopes," "faint hopes," "hopes were raised for nothing," and "he wished, but not with hope." $(1958,127)$

It is noteworthy that the above-quoted entry from $O E D$ (see section one) also defines hope as "expectation of something desired; desire combined 
with expectation." As Wheatley argues, belief in the physical (not merely logical) possibility of $p$ is vital as it makes hoping different from wishing; one can wish for something which is deemed physically impossible, but one cannot hope for the physically impossible $(1958,130)$. Significantly, Wheatley's analysis is concerned with the ordinary use of the words wish and hope (in their propositional sense); it does not address normative issues, i.e. the problem of what makes a particular hope rational and justified.

In contrast, John Patrick Day (1969), when discussing the normative problem of conditions under which one has a right to hope that $p$, sets very low standards for what "probability" of $p$ means:

By "probable" I mean "probable in some degree, however small (e.g. 1/100)." This use is therefore wider than the usual one, since in common speech "probable" means "more probable than not (or greater than 1/2)." (DAY 1969, 95)

And he continues:

$A$ has a right to hope that $P$ when: (1) $A$ 's wish that $P$ is neither immoral nor imprudent, and (2) $A$ 's hope that $P$ is reasonable. ... Condition (2) manifestly calls for an analysis of "reasonable hope." " $A$ 's hope that $P$ is reasonable" is true when: (1) $P$ has some degree of probability, however small; and (2) the degree of $A$ 's probabilityestimate that $P$ corresponds to the degree of probability of $P$; and (3) $P$ is consistent both with itself and with $A$ 's other objects of hope, $Q, R$, etc. $(1969,99)$

Day's account is representative of the so-called "standard account" of hope. ${ }^{37}$ To show how the view on rationality of hope proposed in this paper differs from the standard account, it will be helpful and convenient to successively analyse conditions (1-3) from the above quotation. I believe there are several problems connected with thus defined reasonableness of hope.

To start with the last condition: for a reasonable hope it is not enough to be "consistent both with itself and with $A$ 's other objects of hope." Firstly, a broader term than consistency is needed to define a reasonable hope; two hopes may be logically consistent (e.g. I hope that I will receive a grant and

${ }^{37}$ See also DownIE (1963). Regarding the concept of possibility that is at issue: in their historical survey of conceptions of hope, Bloeser and Stahl write that "all views (except WhEATLEY 1958) allow for cases of hope in which the outcome is extremely improbable; in other words, no lower bound to the probability is required for hoping" (2017: section 3). However, these views do not always represent a normative approach (in some, a descriptive perspective is adopted), whereas Day (see above) is explicit that his analysis of reasonableness concerns $A$ 's "right to hope." 
I hope that the current inflation will decrease), but their consistency does not contribute in any way to their reasonableness. It seems that a more suitable notion would be coherence; reasonable and rational hopes should form a coherent system, not a merely consistent one. Another problem with (3) is that $p$ is supposed to be consistent with itself and A's other objects of hope. However, in a reasonable hope, the propositional content $p$ should be consistent and coherent, first of all, with A's system of beliefs, not her hopes. One could easily imagine a fully consistent (and coherent) system of $A$ 's hopes which would be completely irrational, without any correspondence with the external world. It is hard to see how coherence with a system of other hopes might render a particular hope reasonable. ${ }^{38}$

The next problem concerns (2) ("the degree of $A$ 's probability-estimate that $P$ corresponds to the degree of probability of $P$ "). This condition, as it is formulated ${ }^{39}$ appears too demanding. I believe that a rational epistemic agent should proportion her probability-estimate that $p$ to the evidence possessed by her; this is what standard accounts of evidentialism require. ${ }^{40}$ She cannot be blameworthy for not considering all the factors that bear upon the degree of $p$ 's probability, including those of which she cannot know. It is assumed here that epistemic responsibility is an internalist concept; hence, an appraisal of the rationality of one's beliefs and hopes must depend on elements that are internal to the subject's conscious states of mind and are accessible to her reflection. ${ }^{41}$

The most contentious issue, however, is condition (1) concerning the degree of probability that $p$. According to Day's account, $A$ has a right to hope for what is very unlikely $(1 / 100)$. Can such hope be deemed rational/ reasonable? This is doubtful (I assume that the meaning of reasonable largely overlaps, in this context, with the meaning of rational). When discussing the issue of low probability of $p$, Day refers to the differences between belief and hope (in its estimative aspect):

${ }^{38}$ It must be noted here that also coherence with other beliefs cannot, by itself, make one's particular belief that $p$ (or hope that $p$ ) rational and justified. It is beyond the scope of this paper to discuss the numerous objections to coherentist theories of justification (the-isolation-from-theworld problem, the vagueness of the notion of "coherence," and others; they are discussed elsewhere, cf. BonJour (1985, 97-99; 1999, 124); DAvidson (1986); Olsson (2017). Nonetheless, coherence with other beliefs seems, prima facie, far more desirable for hope's rationality than coherence with other hopes.

${ }^{39}$ See pp. 93, 99, and 100 in Day (1969).

${ }^{40}$ See Feldman and Conee (1985).

${ }^{41}$ See BonJour $(2003,7-8)$. 
$[\mathrm{O}]$ ne of the tests of the reasonableness of a hope is not a test of the reasonableness of a belief. This is the test which requires that the object of hope, $P$, shall have some degree of probability, however small. For it is in order to say " $A$ 's hope that $P$ is reasonable although $P$ is improbable." But it is not in order to say " $A$ 's belief that $P$ is reasonable although $P$ is improbable." $(1969,101)$

It is true that constraints on what may be considered rational belief and what we may call rational hope are different; in the former case, they are far more restrictive. However, these two sets of constraints cannot be conceived of as completely unrelated to each other. $A$ 's belief that $p$ obtains/will obtain - which is part of $A$ 's hope that $p$ - should definitely have a higher degree of probability than $1 / 100$ to deserve the name of "rational hope." Let us remember that intellectual virtues are defined as dispositions properly motivated and reliably truth-conducive. It is difficult to set standards of truthconduciveness, ${ }^{42}$ but an epistemic strategy which allows for $99 / 100$ failure cannot be regarded as truth-conducive. Therefore, hope for something so unlikely cannot be considered a virtuous, rational and epistemically justified hope; it is most likely to generate disappointment and frustration.

At this point, I would like to refer to three, more recent studies on hope and its rationality offered by Luc Bovens (1999), Nicholas H. Smith (2008) and Adrienne M. Martin (2013). All of them are critical-for various reasons - of the "standard," or "orthodox," account of hope as exemplified by Day's (1969) and Downie's (1963) publications. They consider the standard view on hope (with its binary structure: desire plus belief) inadequate but, significantly, they do not question the above-mentioned extremely low boundary of the probability of $p$ required for rational hoping. It must be noted, however, that these three studies are fairly comprehensive in scope and do not focus specifically on the estimative aspect of hope discussed in the present section, i.e. what makes some of our hopes rational and epistemically justified. Rather, they aim to account for the phenomenon of hoping in general: what it means for a given person to hope, which mental and emotional states are involved, how to defend hope against sceptic arguments, or why in certain circumstances, given the same emotional and cognitive attitudes, some people hope and others despair about the desired outcome. Notwithstanding the descriptive viewpoint, when analysing the problem of how we hope and the value of hope, these three authors do not avoid normative issues and offer significant insights concerning hope's rationality. Select theses and arguments from these three studies will be addressed in what follows.

\footnotetext{
${ }^{42}$ See Goldman (2012 [1979], 38).
} 
When considering the nature of hope, Luc Bovens writes:

...one cannot hope for some state of the world, unless one has a degree of credence that it will come about which ranges between some threshold value close to 0 for confidence that it will not come about and some threshold value close to 1 for confidence that it will come about. ... Furthermore, one cannot hope for some state of the world, unless one has some desire that it will come about. But the conjunction of non-confident belief and desire is a necessary and not a sufficient condition of hope. There is no conceptual confusion in affirming one's desire for some state of the world and one's belief that this state may or may not come about, while denying that one is hoping that it would come about. (1999, 673-674; emphasis added)

The conjunction of belief and desire known from the standard account is regarded as insufficient because, according to Bovens, an adequate account of hope must require that the hoper devote some mental energy to thinking what it would be like if the hoped-for outcome were materialized. Thus, apart from having the desire that $p$ and belief that $p$ is possible, the hoper must be engaged in "mental imaging" concerning $p$; otherwise, she cannot be said to hope that $p$.

The question arises whether that additional condition introduced by Bovens is really necessary. Undoubtedly, hoping that $p$ involves mental imaging of some projected state of the world - what it will be like when my hope that $p$ comes true. However, Bovens seems to underestimate the scope of the desiderative and cognitive aspects of hope found in the standard account. Regarding the former, a desire for something unavoidably involves experiencing a whole spectrum of mental imaging related to the desired-for object/outcome, i.e. dreaming or anticipation of what it would be like if the desire were satisfied, how it could happen, feeling pleasure at anticipating the desired course of events, etc. Therefore, if I desire $p$, I must be engaged in at least some mental imaging concerning $p$; otherwise, I can hardly say that I am experiencing what is called "desire." Furthermore, the estimative aspect of hope also requires mental imaging. My belief that $p$ is possible/ probable is a propositional attitude of accepting $p$ as possible/probable, and that mental acceptance involves at least some mental activity on my part connected with judging $p$ 's probability. Moreover, to understand the meaning of $p$ is to know the conditions under which $p$ is true or false. How could we understand the meaning of $p$ without somehow representing and imagining it in the mind as a real state of affairs? Therefore, it must be concluded that "mental imaging" is a constitutive part of both elements of hope present in the standard account, and Bovens" amendment is unnecessary. 
What I would like to concentrate on is Bovens" rebuttal of the sceptic view and his defence of the value and rationality of hoping (1999, $669 \mathrm{ff}$.). According to the sceptic view on hope, life without any hopes is always better than life in which one has hopes. The sceptic argument has it that if we do not hope for anything, we avoid being disappointed and frustrated when some desirable state of affairs does not obtain. On the other hand, when that desirable state of affairs does come true, we can fully enjoy it and there seems nothing to be gained from our prior having hoped for it. What is more, without any prior hopes, we do not risk the prospect that a desirable and really obtaining state of affairs cannot be fully enjoyed because it proves slightly less satisfying than the one we hoped for. Now, considering the advantages of the sceptic position, how can we defend the view that it may be rational to allow ourselves to hope?

As rightly noticed by Bovens, the sceptic view may appear convincing only in circumstances when our hoping for $p$ (or lack of hope) has no influence on the occurrence of $p$. Where the relevant states of the world areat least to some degree - causally dependent on our choice whether to hope or not to hope (and the resulting agency or lack thereof), the sceptic position will lead to failure in achieving the desirable outcome. On numerous occasions, our hoping attitude is advantageous as it triggers success-conducive energy and activity towards reaching a goal, or it helps to see alternative, equally satisfying but more attainable goals. Also, hope helps to see possible gains and overcome fear in risk-taking situations; if not for hope, we might lose many valuable opportunities to achieve our aims only due to shortsighted, fearful fixation on possible losses and, in result, choosing riskavoiding strategy. Importantly, in times of hardship, hoping may provide much needed consolation and respite - this may be vitally important for consolidating the inner strength to cope with difficulties.

Moreover, hoping can also be beneficial (and rational) in cases in which we cannot point to its evident and direct instrumental value. Firstly, because our hopes, along with our beliefs, desires, fears and other mental states, form a multidimensional web-like structure, hoping always results in our increased self-reflection and self-understanding; so it has an epistemic value. Also, that web-like structure of hopes, beliefs and desires can be advantageously reorganized when we devote some mental energy to hoping and considering the hoped-for state of affairs - for example, we may realize that the hitherto desirable object is not so worth hoping for and direct our attention elsewhere. Another reason to vindicate hope against the sceptic 
arguments is that hoping may be a source of considerable "pleasure in the mind," to use Locke's words. That pleasure coming from anticipating the desired state of affairs surely enhances the quality of our life. Additionally, hope for someone's well-being is constitutive of love for that person, and hope for our own well-being is part of our sense of self-worth (Bovens 1999, 675-678). Therefore, despite the possibility of disappointment and frustration, it can be concluded that life with hope is a better life than life without hope. Significantly, potential disappointment need not be given undue weight. As Bovens argues:

our hopes are fluid and often do not need to be abandoned in the face of frustration. Rather they painlessly leave the stage of our mental lives as we learn and shift our hopes towards states of the world that are more attainable or that are more in line with what we truly want. $(1999,676)$

Nonetheless, the position advocated for by Bovens is rather balanced; he does acknowledge a tension between hope and epistemic rationality. Since mental imaging may obscure the boundary between reality and fancy, hoping may easily turn into wishful thinking in which expectation far outweighs the available evidence. The more so that hoping is often accompanied by the illusion of causal agency - in that respect, it resembles prayer. This illusion of agency may result from erroneous generalization of the feature found in certain cases of hoping (in which hoping is conducive to the desired outcome and instrumentally rational) to all other cases, including hopes in which the probability of success is rather low and thoroughly unrelated to our mental states. In Bovens" account, hope is ascribed unquestionable value - instrumental and epistemic - but it is admitted that hoping carries with it the threat of wishful thinking, overestimation of probability and consequent frustration. Therefore, well-tuned hoping requires careful balancing the benefits and pleasures of hoping against the circumstances, probability of the desired outcome and the hoper's ability to tolerate possible frustration (1999, 678-680).

In "Analysing Hope" (2008), Nicholas H. Smith recognizes several reasons why the "standard account" of hope, dating back to Hobbes, Locke, and Hume, is explanatorily useful, but he also points to an important aspect of hoping that the standard account fails to grasp, namely the phenomenology of hope. Apart from the conative and cognitive dimensions of hope (i.e. desire combined with probability estimate), an adequate account needs to describe how hope is experienced by the hoper. What is underlined by Smith, 
hoping is more concerned with anticipation than expectation. ${ }^{43}$ The latter notion suggests a slightly higher probability of the outcome as well as some mental distance; i.e. in expectation, the hoper adopts an "awaiting" attitude to the course of events and the expected outcome. In contrast, when we anticipate a desirable but uncertain object/event, we adopt a more active stance; we are as if united with the desired objective and saturated with "readiness for action" to achieve it. Thus, hoping is not a passive attitude but a lived, intensive experience, "an active orientation, a stance we take up and not just a feeling to be suffered or enjoyed" (SMITH 2008, 17-18). Connected with anticipation is the feeling of "suspense" and uncertainty about one's future. That suspense is not merely a result of a detached, cool estimation of the outcome's probability; it comes from the hoper's engagement and immersion in the desired and projected state of the world. ${ }^{44}$ Smith is right to notice that this phenomenological and more holistic view on hope was somewhat absent from the analytical "standard account," which combined - but usually analysed separately - the conative and cognitive aspects of hoping.

Another significant problem raised by Smith is the question whether we can rationally hope that $p$ in a situation when we have no idea about the future outcome, its probability, conditions of obtaining, etc., and thus, the probability of $p$ is essentially non-estimable from today's perspective - we simply do not know enough. Many people would say that this is the proper situation for hoping; when our understanding and control of the circumstances are very limited or none at all, what we are left with is hope. But can this type of hoping, when probability estimates are unavailable or pointless, be regarded as rational and justified?

Smith argues that, on some occasions, rationality of hope may require "acknowledgement of the non-estimability of the likelihood of a hoped for objective rather than just an acknowledgement of uncertainty about the objective"; and significantly, that acknowledgement of our limited powers of judgment - in itself a demand of reason - "makes room for hope independent of considerations of probability" $(2008,21)$. As concluded by him, it is important that rational and well-tuned hoping be "not foreshortened by what seems reasonable and rational by current standards" (SMITH 2008, 22).

Is the above conclusion still in line with the demands of epistemic responsibility? Can we rationally hope for the unknown? This is a complex

${ }^{43}$ See also Waterworth (2004, 8 ff.); pace the definition from $O E D$ quoted above and WHEATLEy (1958).

${ }^{44}$ See also WALKer $(2006,48)$. 
issue related not only to the preferred epistemic strategy - whether we value epistemic watchfulness or we prefer not to deprive ourselves of "pleasures in the mind" and possible gains - but also, foremost, to what is at stake, and whether any alternative outcomes are available.

The situations when stakes are high - no less than one's life - and the probability of a positive outcome is non-estimable or extremely vague are nothing unusual. During wartime, natural disasters, or in terminal diseases people often hope for a virtually unknown, unpredictable and hazy outcome because this is the only hope available. Such "hope against hope" is psychologically and pragmatically justified - so it is reasonable - though it may lack proper epistemic justification. But when the only alternative is plunging into despair, we cannot afford to be epistemically too ambitious and deprive ourselves of hope and life-sustaining motivation. On the other hand, one could wonder whether such cases of hope for the unknown are relevant to the issue of what makes a particular hope that $p$ rational and justified. It appears that cases of hope for the outcome whose likelihood is non-evaluable or little-understood can be better accounted for as exemplifications of the disposition of hopefulness, possibly combined with trust and faith, rather than hope in the propositional sense that we are concerned with in the present section (see the distinction between hope-in and hope-that in section one and Marcel's concept of "absolute hope").

A markedly different approach to the notions of hope and hope's rationality is proposed by Adrienne M. Martin (2013). In her comprehensive account of hope, she considers the phenomenon of "hoping against hope" as a paradigmatic case where the "orthodox" account (i.e. desire plus probability estimate) proves wanting and misses out what is the key element of hope. To exemplify the point, two patients with incurable disease may have the same strong desire to live, be likewise aware of an extremely low probability estimate of recovery $\left({ }^{1} / 100\right)$, but they may vastly differ in their attitudes. One may remain hopeful that things will go all right, and the other may fall into despair. What the standard account cannot accommodate is the above-mentioned phenomenology of hope and its holistic, syndrome-like nature, irreducible to the two, desiderative and estimative, constituents. According to Martin (2013,6-7), hope is better accounted for as a syndrome encompassing not only desire for a given outcome and probability judgment, but a whole range of related feelings, modes of perception, thoughts, motivational states, planning and activities. Significantly, that syndrome has one unifying element which is our ability to reflect on our own attitudes and 
mental states, and accept them (or reject) as reasons for our agency. In Martin's account, hope has the following structure:

... to hope for an outcome is to desire (be attracted to) it, to assign a probability somewhere between 0 and 1 to it, and to judge that there are sufficient reasons to engage in certain feelings and activities directed toward it. The element that unifies hope as a syndrome is this final element, which I argue is a way of incorporating hope's other elements into one's rational scheme of ends. $(2013,7-8)$

Thus, hoping does include the two elements known from the standard account - desire and probability estimate — but it also involves the hoper's self-reflection. When we hope that $p$, we perceive the desire for $p$ and possibility of $p$ as justification for engaging in characteristic $p$-related activities, such as anticipating $p$, planning, fantasizing about $p$, etc.; in sum, we "incorporate" our attraction to $p$ into our rational agency.

What is significant for consideration of hope's rationality, the norms governing that incorporation are exclusively practical; the hoped-for outcome must be coherent with and must contribute to the agent's scheme of practical ends. Martin argues that "the justifications to which we commit ourselves in virtue of hoping are practical justifications, ... there are few epistemic or theoretical limitations on rational hope" $(2013,9)$. In other words, in Martin's account, rationality in hoping is a matter of practical aims; it is not much concerned with the proper grounds for epistemic justification of probability estimates.

Thus, returning to the foregoing example of the two incurably sick patients, a person with a very low likelihood of recovery $\left({ }^{1} /{ }_{100}\right)$ may still $\mathrm{ra}$ tionally hope to recover if she sees her hoping attitude as coherent with and contributing to her practical aims. What is important to note, a person choosing to hope against very slim odds $\left({ }^{1} / 100\right)$ need not deceive herself that the odds are in fact better than they really are (say 1/4). She may take 1 percent chance - low as it is - as enough to go forward and sufficient to justify her hopeful feelings and activities. It is not the sheer value of probability estimate but how one treats it that explains the difference between despair and hope in such cases. When faced with a dire situation, one person may rightfully say that the positive outcome is "possible, but improbable," while another's reaction will be "it is improbable, but possible," and the latter need not be deemed irrational.

It must be remembered, however, that Martin's view on the notion of rationality in hoping is a practically oriented approach (despite the important 
role of self-reflection and reasoning in her theory). Incorporation of elements of hope into one's rational scheme of ends does not provide justification in the epistemological sense of the word. Her analysis of the syndromelike nature of hope with the key role of "incorporation" may be considered a convincing and realistic account of hope (or it may be rejected), but it is a different view on hope's rationality than the one discussed within the standard account, where the rationality of hope that $p$ depends on having proper justification for the belief that $p$ is probable (or only possible).

\section{CONCLUSION}

In real life situations, many of our hopes are too pervasive and deeprooted in the overall scheme of our objectives to be consciously controlled; as a result, they may be difficult to reject when insufficiently justified. Also, hopes are often ill-defined or fluid and half-formed; the hoped-for outcome may appear opaque and lacking in precise expression. Thus, many hopes, due to their indeterminacy and opacity, are not amenable to rational consideration. Nonetheless, hoping has an ineradicable normative dimensionthis is what makes hopes morally and prudentially evaluable. Similar to how we can be held responsible for the quality of insufficiently justified beliefs, we can be criticized for immoral or irrational and futile hopes, poorly grounded in evidence. As the evidentialist argument has it, the strength of our belief ought to be proportioned to the strength of our evidence. ${ }^{45}$ Therefore, one has a right to responsibly believe that $p$ or to rationally hope that $p$ only if one has some evidence relevant to $p$; the evidentialist norm applies to rational beliefs and to rational hopes alike.

It is true that, in dire circumstances, we often turn to hope even though the desired object/course of events is believed to be very unlikely and unsupported by evidence. When the odds of some positive outcome are very small, we may still "hope against hope." Such hopes may be psychologically and pragmatically well justified, especially if stakes are high and alternative desirable outcomes unavailable. Nonetheless, the belief component of such hopes simply lacks epistemic justification if their content is not supported by sufficient evidence, or when the evidence "for" is counterbalanced by the evidence "against." Perhaps there is nothing unpalatable about the situation

${ }^{45}$ See Locke (1975 [1690], IV, xv-xvi); also: Feldman and Conee (1985); Wolterstorff (1996, 226). 
in which many of our hopes are justified in a psychological and pragmatic sense only, whereas epistemic justification is a rare privilege. Nonetheless, we need to be aware that the fact that a given hope is psychologically pervasive and contributes to one's scheme of practical ends does not make it an epistemically justified hope.

\section{REFERENCJE}

Aquinas, Thomas. 1946 [c. 1265-1273]. Summa Theologica. Translated by The Fathers of the English Dominican Province. New York: Benziger Bros.

Aristotle. 2009 [c. 300 BC]. The Nicomachean Ethics. Translated by David Ross, revised with Introduction and Notes by Lesley Brown. Oxford: Oxford University Press.

Augustine of Hippo. 1955 [c. 420]. Enchiridion: On Faith, Hope, and Love. Translated by Albert C. Outler. Grand Rapids, MI: Freebooks.

Bloeser, Claudia, and Titus Stahl. 2017. "Hope." In The Stanford Encyclopedia of Philosophy. Spring 2017 Edition, edited by Edward N. Zalta. Accessed June 2019. https://plato. stanford.edu/archives/spr2017/entries/hope/.

BonJour, Laurence. 1985. The Structure of Empirical Knowledge. Cambridge, MA: Harvard University Press.

BonJour, Laurence. 1999. "The dialectic of foundationalism and coherentism." In The Blackwell Guide to Epistemology, edited by John Greco and Ernest Sosa, 117-142. Malden, MA: Blackwell.

BonJour, Laurence. 2003. "A version of internalist foundationalism." In Laurence BonJour and Ernest Sosa. Epistemic Justification: Internalism vs. Externalism, Foundations vs. Virtues, 3-96. Malden, MA: Blackwell.

Bovens, Luc. 1999. "The Value of Hope." Philosophy and Phenomenological Research, vol. 59, no. 3: 667-681.

Camus, Albert. 1975 [1942]. The Myth of Sisyphus. Translated by Justin O'Brien. Harmondsworth: Penguin Books.

CoвB, Aaron D. 2015. "Hope as an Intellectual Virtue?" The Southern Journal of Philosophy, vol. 53, no. 3: 269-285.

Conee, Earl, and Richard Feldman. 1998. "The Generality Problem for Reliabilism." Philosophical Studies, vol. 89, no. 1: 1-29.

Davidson, Donald. 2001 [1984]. Inquiries into Truth and Interpretation. Second Edition. Oxford: Clarendon Press.

Davidson, Donald. 1986. "A Coherence Theory of Knowledge and Truth." In Truth and Interpretation, edited by Ernest LePore, 307-319. Oxford: Blackwell.

DAY, John Patrick. 1969. "Hope.” American Philosophical Quarterly, vol. 6, no. 2: 89-102.

Dewey, John 2004 [1916]. Democracy and Education. An Introduction to the Philosophy of Education. Delhi: Aakar Books.

Downie, Robin S. 1963. "Hope." Philosophy and Phenomenological Research, vol. 24, no 2: 248-251. 
Feldman, Richard. 1985. "Reliability and Justification.” Monist, vol. 68, no. 2: 159-174.

Feldman, Richard, and Earl Conee. 1985. "Evidentialism." Philosophical Studies, vol. 48, no. 1: $15-34$.

Fodor, Jerry. 1975. The Language of Thought. New York: Crowell.

Foley, Richard. 1985. "What's wrong with reliabilism?" Monist, vol. 68, no. 2: 188-202.

Glock, Hans-Johann. (2003). Quine and Davidson on Language, Thought and Reality. Cambridge: Cambridge University Press.

Goldman, Alvin I. 2012 [1979]. "What is Justified Belief?" In Reliabilism and Contemporary Epistemology: Essays, 29-49. Oxford: Oxford University Press.

Goldman, Alvin I. 2012. Reliabilism and Contemporary Epistemology: Essays. Oxford: Oxford University Press.

Greco, John. 2010. Achieving Knowledge: A Virtue-Theoretic Account of Epistemic Normativity, Cambridge: Cambridge University Press.

Hall, Edward. 1809 [1548]. Hall's Chronicle. London: Printed for J. Johnson, etc.

HobBes, Thomas. 1998 [1651]. Leviathan. Edited with an Introduction and Notes by J.C.A. Gaskin. Oxford: Oxford University Press.

Kant, Immanuel. (2015 [1788]). Critique of Practical Reason. Translated by Mary J. Gregor. Cambridge: Cambridge University Press.

Locke, John, 1975 [1690]. An Essay Concerning Human Understanding. Edited by Peter H. Nidditch. Oxford: Clarendon Press.

MacDonald, George. 1989 [1867]. The Disciple, and Other Poems. [N.p.]: Franklin Classics Trade Press.

Marcel, Gabriel. 1951. Homo Viator. Introduction to a Metaphysic of Hope. Translated by Emma Craufurd. Chicago: Henry Regnery Company.

Martin, Adrienne M. 2013. How We Hope: A Moral Psychology. Princeton, NJ: Princeton University Press.

Meirav, Ariel. 2009. "The Nature of Hope." Ratio, vol. 22, no. 2: 216-233.

Mill, John Stuart. 1969 [1874]. “Theism.” In Essays on Ethics, Religion and Society, 429-489. Toronto: University of Toronto Press, Routledge \& Kegan Paul.

Montmarquet, James. 1993. Epistemic Virtue and Doxastic Responsibility. Lanham: Rowman and Littlefield.

Moser, Paul K. (1999). "Belief.” In The Cambridge Dictionary of Philosophy. Second Edition, edited by Robert Audi, 78-79. Cambridge: Cambridge University Press.

Neumark, Georg Christian. 1855 [1653]. "Hymn." Translated by Catherine Winkworth. Hymnary.org. Accessed June 2019. https://hymnary.org/hymn/SBSA1986/738.

Nietzsche, Friedrich. 1910 [1878]. Human, All-Too-Human. A Book for Free Spirits. Translated by Helen Zimmern. Edinburgh, London: T.N. Foulis.

OLsson, Erik. 2017. "Coherentist theories of epistemic justification." In The Stanford Encyclopedia of Philosophy. Spring 2017 Edition, edited by Edward N. Zalta. Accessed June 2018. https://plato.stanford.edu/archives/spr2017/entries/justep-coherence/.

Pettit, Philip. 2004. "Hope and Its Place in the Mind." Annals of the American Academy of Political and Social Science, vol. 592: 152-165.

Plato. 1997 [c. 350 BC]. Philebus. Translated by Dorothea Frede. In Plato. Complete Works, edited by John M. Cooper, 398-456. Indianapolis, Cambridge: Hackett Publishing Company. 
Plato. 1997 [c. 360 BC]. Timaeus. Translated by Donald J. Zeyl. In Plato. Complete Works, edited by John M. Cooper, 1224-1291. Indianapolis, Cambridge: Hackett Publishing Company.

Plato, 1997 [c. 380 BC]. Republic. Translated by G.M.A. Grube, revised by C.D.C. Reeve. In In Plato. Complete Works, edited by John M. Cooper, 971-1223. Indianapolis, Cambridge: Hackett Publishing Company.

Price, Henry Habberley. 1969. Belief. London: George Allen \& Unwin Ltd.

Roberts, Robert C., and W. Jay Wood. 2007. Intellectual Virtues: An Essay in Regulative Epistemology. Oxford: Clarendon Press.

Schopenhauer, Arthur. 2001 [1851]. Parerga and Paralipomena: Short Philosophical Essays, Vol. 2. Translated by E.F.J. Payne. Oxford: Clarendon Press.

Schwitzgebel, Eric. 2015. "Belief." In The Stanford Encyclopedia of Philosophy. Spring 2019 Edition, edited by Edward N. Zalta. Accessed July 2015. https://plato.stanford.edu/ archives/fall2019/entries/belief/.

SENECA, Lucius Annaeus. 1969 [c. 60 AD]. Letters from a Stoic: Epistulae morales a Lucilium. Translated by Robin Campbell. London: Penguin.

Simpson, John A., and Edmund S.C. Weiner (eds.). 2001 [1989]. The Oxford English Dictionary. Oxford: Clarendon Press.

Smith, Nicholas H. 2008. "Analysing hope." Critical Horizons: A Journal of Philosophy and Social Theory, vol. 9, no. 1: 5-23.

SNow, Nancy E. 2013. "Hope as an Intellectual Virtue." In Virtues in Action: New Essays in Applied Virtue Ethics, edited by Michael W. Austin, 153-170. New York: Palgrave Macmillan.

SosA, Ernest. 1991 [1980]. "The Raft and the Pyramid: Coherence versus Foundations in the Theory of Knowledge." Midwest Studies in Philosophy, vol. 5: 3-25. Reprinted in: Ernest Sosa. Knowledge in Perspective, 165-191. Cambridge: Cambridge University Press.

Sosa, Ernest. 1991. Knowledge in Perspective. Cambridge: Cambridge University Press.

Sosa, Ernest. 2003. "Beyond Internal Foundations to External Virtues." In Laurence BonJour and Ernest Sosa. Epistemic Justification: Internalism vs. Externalism, Foundations vs. Virtues, 97-170. Malden, MA: Blackwell.

Sosa, Ernest. 2007. A Virtue Epistemology. Apt Belief and Reflective Knowledge. Vol. 1. Oxford: Oxford University Press.

SpinozA, Baruch de. 2002 [1670]. Theological-Political Treatise. In Spinoza. Complete Works, edited by Michael Morgan, translated by Samuel Shirley, 383-583. Indianapolis: Hackett.

SpinOZA, Baruch de. 1994 [1677]. The Ethics and Other Works, edited and translated by Edwin Curley. Princeton, NJ: Princeton University Press.

Turri, John, Mark Alfano, and John Greco. 2017. "Virtue epistemology." In The Stanford Encyclopedia of Philosophy. Spring 2019 Edition, edited by Edward N. Zalta. Accessed June 2015. https://plato.stanford.edu/archives/fall2019/entries/epistemology-virtue/.

WalKer, Margaret Urban. 2006. Moral Repair. Cambridge: Cambridge University Press.

Waterworth, Jayne M. 2004. A Philosophical Analysis of Hope. Basingstoke: Palgrave Macmillan.

Wawrykow, Joseph P. 2012. "The Theological Virtues.” In The Oxford Handbook of Aquinas, edited by Brian Davies and Eleonore Stump, 287-307. Oxford: Oxford University Press.

Wheatley, J.M.O. 1958. "Wishing and Hoping." Analysis, vol. 18, no. 6: 121-131.

WolterstorfF, Nicholas. 1996. John Locke and the Ethics of Belief. Cambridge: Cambridge University Press. 
ZagzeBsKi, Linda Trinkaus. 1996. Virtues of the Mind. An Inquiry into the Nature of Virtue and the Ethical Foundations of Knowledge. Cambridge: Cambridge University Press.

ZagzeBsKi, Linda Trinkaus. 1999. "What is knowledge?" In The Blackwell Guide to Epistemology, edited by John Greco and Ernest Sosa, 92-116. Malden, MA: Blackwell.

\title{
WHY HOPE CANNOT BE AN INTELLECTUAL VIRTUE: RATIONALITY OF HOPE CONSIDERED FROM AN ANALYTIC PERSPECTIVE
}

\author{
Su m m a r y
}

There are two aims of the paper. The first is to critically analyse the claim that hope can be regarded as an intellectual virtue, as proposed by Nancy E. Snow (2013) in her recent account of hope set within the project of regulative epistemology. The second aim is to explore the problem of rationality of hope. Section one of the paper explains two different interpretations of the key notion of hope and discusses certain features to be found in hope-that and hope-in. Section two addresses the question of whether hope could be interpreted as an intellectual virtue. To develop an argument against that view, a brief account of the notion of epistemic virtue is provided. Section three analyses the problem of rationality of hope and the parallels between rational belief and rational hope; the section focuses on what exactly makes a particular hope-that a rational and justified hope. Belief that $p$ is possible/probable is part of the meaning of hope that $p$; therefore, it is assumed that rationality of hope cannot be considered in isolation from rationality of belief. It is argued that the "standard account" of the reasonableness of hope, which is found in the analytic literature, does not meet the standards of epistemic responsibility and needs rectifying.

Keywords: hope-that; hopefulness; intellectual virtue; rationality; propositional attitude; reliability; truth-conduciveness

\section{DLACZEGO NADZIEJA NIE MOŻE BYĆ CNOTĄ EPISTEMICZNĄ - O RACJONALNOŚCI NADZIEI Z PERSPEKTYWY ANALITYCZNEJ}

\section{Streszczenie}

Artykuł ma dwa podstawowe cele. Pierwszym jest krytyczna analiza twierdzenia, że nadzieja może być uznana za jedną z cnót epistemicznych czy też intelektualnych, jak to proponuje Nancy E. Snow (2013) w artykule osadzonym w ramach epistemologii regulatywnej. Drugim celem jest rozpatrzenie problemu racjonalności nadziei. Artykuł przedstawia dwie różne interpretacje pojęcia nadziei: jako postawy propozycjonalnej (hope-that p) i jako ogólnej dyspozycji (hope-in $x$ ) (część pierwsza). W części drugiej rozpatrywane jest zagadnienie tytułowe: czy nadzieja może być uważana za cnotę epistemiczną. W celu rozwinięcia argumentu przeciwko takiej interpretacji nadziei, przedstawiona jest krótka charakterystyka rozumienia pojęcia cnoty epistemicznej w obrębie epistemologii cnót. W części trzeciej analizowany jest problem racjonalności nadziei (jako postawy propozycjonalnej). Szczególną uwagę poświęcono cechom wspólnym, które łączą racjonalne przekonanie i racjonalną nadzieję. W części tej rozpatrywane jest pytanie o warunki konieczne, które musza być spełnione, aby nadzieję można było uznać za postawę racjonalną i uprawomocnioną. W artykule zakłada się, że skoro przekonanie, że $p$ jest możliwe/ prawdopodobne, jest częścią składową nadziei, że $p$, kwestia racjonalności nadziei nie może być rozpatrywana zupełnie niezależnie od zagadnienia racjonalności przekonań. Przedstawiona jest 
argumentacja, dlaczego tzw. stanowisko standardowe co do racjonalności nadziei przedstawiane w epistemologii analitycznej nie spełnia wymagań epistemicznej odpowiedzialności i wymaga skorygowania.

Słowa kluczowe: nadzieja, że $p$; postawa nadziei; cnota epistemiczna; racjonalność; postawa propozycjonalna; reliabilizm; wiarygodność.

Informacje o Autorze: dr hab. ELŻBIETA ŁUKASIEWICZ, PROF. UCZELNI - Uniwersytet Kazimierza Wielkiego w Bydgoszczy, Wydział Językoznawstwa, Katedra Językoznawstwa Angielskiego; adres do korespondencji: ul. Grabowa 2, 85-601 Bydgoszcz; e-mail: el.lukas@ukw.edu.pl; el.lukasiewicz@gmail.com; ORCID: https://orcid.org/0000-0002-9121-0016. 